\title{
Mobile Game Adoption in China: the Role of TAM and Perceived Entertainment, Cost, Similarity and Brand Trust
}

\author{
Guoyin Jiang ${ }^{1}$, Ling Peng ${ }^{* 2}$ and Ruoxi Liu ${ }^{3}$ \\ ${ }^{1}$ School of Information Management, Hubei University of Economics \\ School of Information Management, Wuhan University \\ *2, ${ }^{3}$ School of Information Management, Hubei University of Economics \\ 1jiangguoyin@hbue.edu.cn, ${ }^{2}$ buaapl@aliyun.com,116497716@qq.com ${ }^{3}$
}

\begin{abstract}
The mobile game is experiencing a rapid development and one of the favorite mobile applications. This article focuses on Chinese mobile game market and conducts an empirical research on the factors of the user adoption of mobile game. The research results show that perceived usefulness, perceived entertainment, economic cost and subject norm significantly affect the attitude of use, which results in behavior intention to adopt the mobile game, while the perceived ease of use, similarity and brand trust, which proposed to affect the user adoption in related literatures insignificantly affect use adoption of mobile game .
\end{abstract}

Keywords: User Adoption, Mobile Game, Perceived Entertainment

\section{Introduction}

With the development of network technology, network game is experiencing a golden period of development and it is making biggest profit for network service vendors. As a new branch of network game, mobile game is main revenue growth point upon network game.

At present, China has more than 720 million mobile phone users, over $50 \%$ penetration rate of the total population. At present, China has more than 500 million people surf the Internet through mobile phones, accounting for 80.9 percent of all netizens in China [1]. The stable growth of netizens scale in China provides a favorable external environment for the development of the mobile game market. With the wireless network greatly improved in China, the content of mobile game is also growing. In addition, popularity of smart phones has greatly stimulated user experience of mobile games, mobile games is becoming a high-growth business in China.

Facing the huge development potential in mobile game market, some leading companies, Apple, Nokia, Grand, Dexin, EA moved into the business of mobile game. In order to occupy the advantageous position in the market structure, the mobile game operators compete in launching the latest mobile game through technical research and development, technology upgrades. Not only the advancedness of the mobile game itself can affect the consumer purchase decision, but consumer insight into the mobile phone game is also the key factors. Therefore, this article carries out a study of the factors affecting user adoption of mobile games by the empirical study in China market.

\footnotetext{
*Corresponding author

The $1^{\text {st }}$ version of the work is represented in 2014 International Conference on Logistics, Informatics and Services Sciences (LISS'2014), Berkeley,California,USA.
} 


\section{Literature Review}

\subsection{Mobile Game Related Study}

Studies on mobile game mainly concentrated in optimization of mobile game platform or technology improvement and development $[2,3]$, and few scholars from the angle of user preference to study the mobile game user adoption behavior.

Harris et al. (2005) and other scholars studied the influence of the culture on mobile commerce adoption by comparing the UK and Hongkong. It found that users from Britain and Hongkong have different attitudes to the mobile business service [4].

Liyi Zhang et al. (2012) discovered the factors of mobile commerce adoption by conducting a meta-analysis of related empirical studies. The moderating effect of culture was also proved by dividing the samples into subgroups of eastern and western culture [5].

Because our study focused on Chinese mobile game market, the related research results from Chinese market should be paid extra attention. Actually the research in this area is not very rich. The limited studies mainly concentrated in the following three aspects.

First, the application of some technologies in the development and product design of mobile game. Some Chinese researchers focus on the applications of the electronic games to mobile phones by some information techniques, such as J2ME, Bluetooth and 3D imaging (Di Feng, 2007; Zhixiao Zhou, 2009; Tianshun Wang ) [6-8].

The second is the analysis on the user adoption or behavior of some applications in e-commerce and mobile commerce. This related studies proposed mobile commerce service adoption based on TRA, TAM, and some other typical user acceptance model with combing some new factors according to the application context, such as customer trust, customer loyalty, user perceived cost, and so on.

Zhaohua Deng et al. (2010) compared the attitude of adopters' and non-adopters' on mobile services. Perceived usefulness and perceived cost influenced the two groups, and the continued usage was positively affected by perceived trust and perceived trialability [9].

There is also study focusing on a certain factor affecting mobile commerce user adoption. Jiabao Lin et al. (2014) proposed a three-stage trust evolution model of mobile banking user, which included the trust in pre-usage stage, usage stage, and post-usage stage. The empirical results show that the pre-use trust affects the user behavior directly and indirectly, and user satisfaction improves the trust in post-usage stage, which will in turn influence future usage behavior. The long-term impact of pre-use trust on post-use trust was proved [10].

Zhaohua Deng (2008) added the factor trust into the technology acceptance model (TAM) and trust to verify the factors of the subscription to mobile services. The influence of Perceived usefulness, perceived trust, and perceived cost of mobile services on mobile service user's behavioral intention was proved [11].

Third, there are some studies on consumer behavior of mobile phone game. Based on the Technology Acceptance Model, those factors verified in many related mobile commerce studies, perceived usefulness, perceived ease to use and subjective norm, combined with some new constructs, such as perceived joy, game design, and relative advantages are proved to be have effect on the mobile game acceptance in Chinese market.(Cheng Wang, 2010) [12]. And Chang Liu (2013) attributed the success of the mobile game promotion to the factors influencing user acceptance, which are content innovation, playtime, social network experience, and ease of use [13]. 


\subsection{Related Theory of Technology Acceptance/User Adoption}

2.2.1 The Theory of Reasoned Action (TRA): The theory of reasoned action was proposed by American scholars Fishbein and Ajzen in 1975, which is mainly used to analyze the influence of the attitude on individual behavior. The basic assumption is that people are rational, who will synthesize information to make an act by considering the significance and consequences before their behavior.

TRA verified that individual behavior can be reasonably inferred from behavioral intention to some extent, and the individual's behavioral intention is determined by behavioral attitudes and subjective norms. People's behavior intention is a measure of the people going to engaged in a particular behavior, and the attitude is positive or negative emotions that people held by when they engaged in a target behavior, it is decided by the main beliefs on behavior and the results of the estimated important degree. Subjective norm refers to that the individual feel social pressure when decide whether to take a particular action, which means the influence of individual (or groups) on individual behavior decision making should be considered, when predicting behaviors. These factors combined, will produce behavior intention (tendency), eventually lead to behavior change.[14]

2.2.2 Theory of Planned Behavior: Theory of planned behavior is proposed by Icek Ajzen (1988, 1991). Ajzen expanded TRA by finding that people's behavior is not absolutely voluntary, but under control. He added a new concept of the self 'behavior control cognition' (Perceived behaviors Control), which formed the new theory of behavior pattern -- the theory of planned behavior.

It includes four levels: the actual behavior of consumers; the consumer's behavior intention; the factors affecting consumer behavior, namely, consumer attitude, subjective norm and perceived behavioral control; the fourth level is the factors affecting the above attitude, subjective norms, perceived behavioral control [15].

2.2.3 Technology Acceptance Model (TAM): The technology acceptance model (TAM) is a model proposed by Davis In 1989, who applied TRA on user acceptance of information system. The technology acceptance model proposes two main factors: usefulness of perception (perceived usefulness), reflecting a person thinks of the degree of his work performance improved by using a specific system; perceived ease of use, reflects the degree of a person easily using a specific system.

According to TAM, system using is decided by behavioral intention, and behavioral intention is decided by attitude to use and perceived usefulness, attitude to use refers to an individual's persistence cognition, feelings and tendencies to something or concepts; Behavioral intention refers to the strength of the individual plans to adopt a particular behavior. Perceived usefulness to use has a significant positive impact on user's attitude and behavior intention, and perceived ease of use of significantly affects the user's attitude and perceived usefulness [16,17].

Though the previous references concentrated in the factors of mobile commerce acceptance are rather fruitful, each specific e-commerce application has its unique features. By considering the majority of the existed conclusions about mobile commerce acceptance are from the empirical studies on a specific application of mobile commerce or on the mixed applications without subdivision, we should pay extra attention on the characteristics of mobile game.

Therefore, this study, from the perspective of user acceptance behavior, based on the technology acceptance model (TAM), adds entertainment of the perceived, economic cost, brand trust, similarity and subjective norms into technology acceptance model, to strengthen the ability of technology adoption model in explaining. 
Three problems will be solved in this study: first, the cognitive situation of mobile game user. Second, what factors affect the user to adopting mobile game. Third, how and to what degree the factors influence mobile game user acceptance.

\section{Research Model and Hypothesis}

\subsection{Research Model}

The purpose of this study is to investigate user adoption factors of mobile phone game acceptance within China. As discussed, research model presented in this paper is extended based on the TAM model, which retains the essential structure, referenced to many literatures on mobile commerce user adoption behavior $[18,19]$. Combined with the characteristics of mobile game, the research model in this paper considers five external factors: perceived entertainment, economic cost, brand trust, similarity and subjective norm. User behavior intention, as the main index, predicts and explains the user adoption behavior. The mobile game user adoption model is as shown in Figure 1.

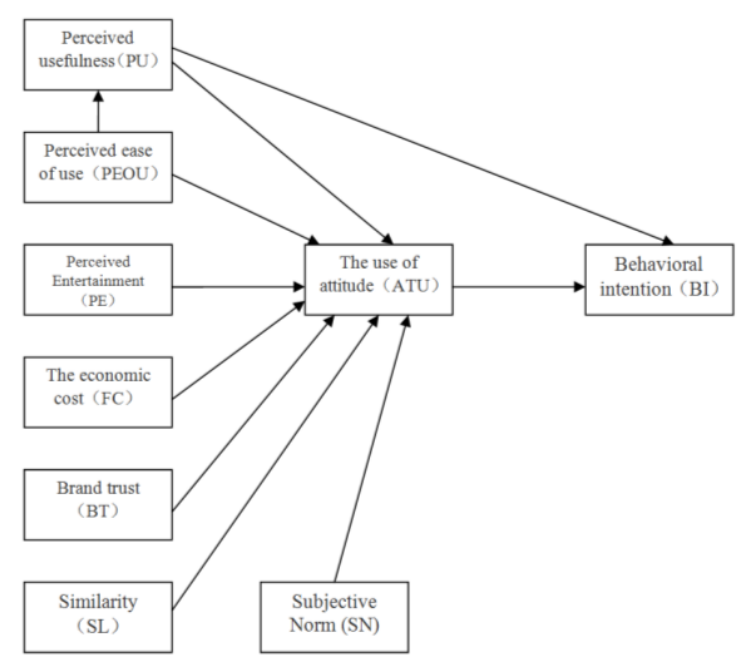

Figure 1. Mobile Game User Adoption Model

\subsection{The Study Variables}

3.2.1 Perceived Entertainment: Perceived Entertainment refers to the degree of mobile game user feel interesting and intrinsic enjoyment. In the studies on the new technology user adoption, scholars have recognized that perceived entertainment has a significant effect on the user's attitude [18-19].

Table 3-1. Perception of Recreational Scale

\begin{tabular}{|l|l|}
\hline $\begin{array}{l}\text { Measurement of latent } \\
\text { variable }\end{array}$ & corresponding questionnaire \\
\hline perceived entertainment & I think playing mobile games, time will pass quickly \\
\cline { 2 - 2 } & $\begin{array}{l}\text { Playing the latest and most popular mobile games, to some extent reflects } \\
\text { the young and trendy }\end{array}$ \\
\cline { 2 - 2 } & Mobile games brings to me satisfied entertainment experience \\
\hline
\end{tabular}

3.2.2 Economic Cost: Economic cost refers to the mobile communication traffic fee or download fee that the user pay for in the process of using mobile game. User acceptance tends to be affected by the economic cost when user considers accepting service or using 
a product. Related researches show that: the economic motivation is often the important factor influencing the adoption behavior of information system [20].

Table 3-2. Economic Cost of Inventory

\begin{tabular}{|l|l|}
\hline $\begin{array}{l}\text { Measurement of } \\
\text { latent variable }\end{array}$ & corresponding questionnaire \\
\hline Economic cost & I think that the use of mobile game flow fee or monthly fee is too high. \\
\cline { 2 - 3 } & I usually choose free or low cost game \\
\cline { 2 - 2 } & I think if the mobile games cost is low, the use of the people will be more. \\
\cline { 2 - 2 } & $\begin{array}{l}\text { If the mobile game of the high ratio of performance to price, I will consider the } \\
\text { purchase price higher game. }\end{array}$ \\
\hline
\end{tabular}

3.2.3 Brand Trust: Brand trust is defined as the belief in security, dependability and ability of the e-commerce environment in the absence of risk, and consumers feel the level of game manufacturers can maintain the interests of the player [21].

According to the definition above, brand trust in this study is defined as loyalty of mobile game player to a certain brand of mobile game.

Table 3-3. Brand Trust Scale

\begin{tabular}{|l|l|}
\hline $\begin{array}{l}\text { Measurement of latent } \\
\text { variable }\end{array}$ & corresponding questionnaire \\
\hline Brand trust & I have a relative like game or series of brand. \\
\cline { 2 - 2 } & $\begin{array}{l}\text { I will be the first choice of the brand / product series when I need this kind } \\
\text { of products, }\end{array}$ \\
\cline { 2 - 2 } & I like the new game of mobile game developers launched, I like to play \\
\cline { 2 - 2 } & $\begin{array}{l}\text { I like the computer game launched mobile phone edition, I am willing to } \\
\text { play }\end{array}$ \\
\hline
\end{tabular}

3.2.4 Similarity: With the development of mobile technology, mobile devices are feature-rich. We found that mobile game selection is often constrained by the performance of mobile devices. For example, using iPhone or other phones with large touch screen, users tend to choose games like fruit ninja, etc., which visual touch can fully demonstrate the performance of mobile. While less users use mobile with small screen function, and those users are less demand for game. Therefore, we add a new variable in the mobile game adoption model, the similarity between the performance of user's mobile phone and the functions what the mobile games needed [22].

Table 3-4. Similarity Scale

\begin{tabular}{|l|l|}
\hline $\begin{array}{l}\text { Measurement of latent } \\
\text { variable }\end{array}$ & corresponding questionnaire \\
\hline similarity & $\begin{array}{l}\text { My mobile phone is powerful, I would like to play games on the mobile } \\
\text { phone. }\end{array}$ \\
\cline { 2 - 2 } & $\begin{array}{l}\text { Mobile phone game better fits mobile phone functions, makes it easy to } \\
\text { operate on the game }\end{array}$ \\
\cline { 2 - 2 } & $\begin{array}{l}\text { I like to play the game that can make use of advantage (sense of touch, the } \\
\text { screen size) my mobile phone function }\end{array}$ \\
\hline
\end{tabular}

3.2.5 Subjective Norm: Subjective norms, based on TRA, also known as social norms, refers to the user feels the degree of the behavior effected by social (media and enterprises), others (friends, colleagues, etc.) and self control (self image, cognitive ability, etc.) when adopting mobile game [23].

\section{Table 3-5. Subjective Norms of Scale}

\begin{tabular}{|ll|l|}
\hline $\begin{array}{l}\text { Measurement } \\
\text { latent variable }\end{array}$ & of & corresponding questionnaire \\
\hline
\end{tabular}




\begin{tabular}{|l|l|}
\hline Subjective norm & According to my observation, the number of the use of mobile game is very large \\
\cline { 2 - 2 } & Almost all my friends are playing mobile games \\
\cline { 2 - 2 } & $\begin{array}{l}\text { The recommended level of mobile phone game of the relatives and friends would } \\
\text { influence my choice }\end{array}$ \\
\hline
\end{tabular}

\subsection{The Research Hypothesis}

3.3.1 The Basic Model of TAM: The model of user adoption of mobile game in this paper is based on the basic TAM model. When the user perceive mobile game can help work and life, increase the pleasure, and make users being more willing to use, then to adopt mobile game. When consumers think that the mobile game is easy to use, they will be more willing to use, which will make them have a positive attitude toward mobile game. Thus, combining the TAM model of the existing research results, to put forward the following hypothesis:

H1a: Perceived usefulness has significant positive influence on the attitude toward the use of mobile game.

H1b: Perceived usefulness obviously influence the behavioral intention of user adoption of mobile games

H2a: Perceived ease of use significantly affects the perceived usefulness of mobile game.

$\mathrm{H} 2 \mathrm{~b}$ : Perceived ease of use has significant positive influence on the attitude toward the use of mobile game.

H3: The mobile game attitude of users has a positively and significantly influence on the behavioral intention of user adoption

\subsubsection{The Modified Model}

\section{(1)Perceived Entertainment}

Pedersen proved that in the study of MMS as the representative of the mobile value-added services, perceived entertainment is an important factor affecting user adoption. The prominent feature of mobile games is to let people feel the joy of experience in the use process, so as to improve the enthusiasm of user adoption of mobile game, and to have positive attitude towards the adoption of mobile game. Therefore, to put forward the following hypothesis:

H5: user perception of mobile games entertaining has a positive influence on using attitude.

\section{(2) Economic cost}

When users think they should pay much for mobile gaming and network traffic, they prone to negative attitude to use. When consumers think that the cost of mobile game is reasonable, they will consider adopting the use of mobile games, which occurred in the use of behavior. Thus, to put forward the following hypothesis:

H6: The economic cost has a significant negative impact on the attitude toward the use of the mobile games.

\section{(3)Brand trust}

The higher loyalty of the user to a game brand, the more trust of the quality of a game which the game brand launched, it will raise the enthusiasm of the adoption of mobile game, and make the use to have a positive attitude to the mobile game. Therefore, to put forward the following hypothesis:

H6: Brand trust positively affects the attitude to the mobile game use.

(4)Similarity 
Because the mobile game is restricted by the performance of mobile phone, the closer to the performance of the mobile games, the higher the enthusiasm of users to use; on the contrary, if mobile phone performance does not match the mobile games, the user is at very low level of enthusiasm for their adoption behavior. Therefore, to put forward the following hypothesis:

H7: similarity of mobile games and mobile phone performance positively and significantly affect attitude to using mobile game.

(5)Subjective norm

Subjective norm means that the individual feel social pressure when decide whether to take a particular action, which means the influence of individual (or groups) on individual behavior decision making should be considered, when predicting behaviors. Therefore, to put forward the following hypothesis:

H8: Subjective norms positively and significantly affect user attitude to mobile game use.

\section{Research and Design}

\subsection{Questionnaire Design}

The questionnaire is the most important tool for the survey data collection. Questionnaire design quality is directly related to the correctness and validity of the conclusion of the study. We modify and clear up the content of the option of questionnaire based on reading other people's literature in combination with the actual situation of the research. The questionnaire in this study is composed of two parts, the first part is the survey of demographic characteristics, including gender, age, education level, occupation and so on; the second part contains measures of all variables in the empirical model. In order to ensure the reliability and validity of the variables, this paper fully reference to the constructs used in relevant literature, to extend and adjust the variables measurement according to the characteristics of mobile game, the specific measurement of each variable and their literature sources are shown in Table 4-1.

Table 4-1. Variable Structure and Source

\begin{tabular}{|c|c|c|}
\hline Latent variable & The observed variables & Source \\
\hline \multirow{3}{*}{$\begin{array}{l}\text { Perceived } \\
\text { Usefulness }\end{array}$} & Using mobile games is helpful to my work or life & \multirow{2}{*}{ Davis (1989) } \\
\hline & In short, mobile game is very useful to me & \\
\hline & Play mobile game can let me kill time or relieve the pressure & self \\
\hline \multirow{4}{*}{$\begin{array}{l}\text { Perceived Ease } \\
\text { of Use }\end{array}$} & I can quickly proficiency in using mobile game & Davis (1989) \\
\hline & $\begin{array}{l}\text { Mobile game better fit the function of the mobile phone, let } \\
\text { me easily to operate on the game. }\end{array}$ & \multirow[t]{3}{*}{ self } \\
\hline & $\begin{array}{l}\text { Mobile phone can carry around, so I would like to play } \\
\text { games with the mobile phone }\end{array}$ & \\
\hline & $\begin{array}{l}\text { I can easily find the mobile phone game I need through } \\
\text { the mobile access platform (such as Apple's App Store, } \\
\text { China Mobile's Mobile Market) }\end{array}$ & \\
\hline \multirow{3}{*}{$\begin{array}{l}\text { Perceived } \\
\text { entertainment }\end{array}$} & I think time will pass very quickly when using mobile game & \multirow[t]{2}{*}{ Pedersen(2005) } \\
\hline & $\begin{array}{l}\text { Mobile games brings to me satisfied entertainment } \\
\text { experience }\end{array}$ & \\
\hline & $\begin{array}{l}\text { Playing the latest and most fashionable mobile games, can to } \\
\text { some extent reflect I am young fashion }\end{array}$ & self \\
\hline \multirow[t]{2}{*}{ Financial Cost } & $\begin{array}{l}\text { I think that the use of mobile game flow fee or monthly fee is } \\
\text { too high. }\end{array}$ & \multirow[t]{2}{*}{ self } \\
\hline & $\begin{array}{l}\text { If there is a preferential tariff policy, I will use more mobile } \\
\text { game }\end{array}$ & \\
\hline
\end{tabular}




\begin{tabular}{|c|c|c|}
\hline & $\begin{array}{l}\text { I think if the lower the cost of the mobile games, the more } \\
\text { people will use }\end{array}$ & \\
\hline & $\begin{array}{l}\text { If the mobile game of the high ratio of performance to price, } \\
\text { I will consider the purchase higher price game }\end{array}$ & self \\
\hline \multirow[t]{3}{*}{ Subject Norm } & $\begin{array}{l}\text { According to my observation, the number of the use of } \\
\text { mobile game is very large }\end{array}$ & \multirow[t]{2}{*}{$\begin{array}{c}\text { Schepers } \\
(2006)\end{array}$} \\
\hline & Almost all my friends are playing mobile games & \\
\hline & $\begin{array}{l}\text { The recommended level of mobile game of the relatives and } \\
\text { friends would influence my choice }\end{array}$ & self \\
\hline \multirow[t]{4}{*}{ Brand Trust } & I have a relative favorite game or series of brand & \multirow{4}{*}{ self } \\
\hline & $\begin{array}{l}\text { When I need this kind of products, I will firstly choose the } \\
\text { brand / product series }\end{array}$ & \\
\hline & $\begin{array}{l}\text { I am willing to play the new game that my pleased mobile } \\
\text { game developers launched }\end{array}$ & \\
\hline & $\begin{array}{l}\text { The computer game that I like launched mobile phone } \\
\text { edition, so I am willing to play }\end{array}$ & \\
\hline \multirow[t]{3}{*}{ Similarity } & $\begin{array}{l}\text { My mobile phone is powerful, I would like to play games on } \\
\text { the mobile phone. }\end{array}$ & \multirow[t]{3}{*}{ self } \\
\hline & $\begin{array}{l}\text { Mobile game better fits mobile phone functions, which } \\
\text { makes it easy for me to operate on the game }\end{array}$ & \\
\hline & $\begin{array}{l}\text { I like to play the game that can express advantage(sense of } \\
\text { touch, the screen size) of the function of my mobile phone. }\end{array}$ & \\
\hline \multirow{2}{*}{$\begin{array}{l}\text { Behavioral } \\
\text { Intention }\end{array}$} & I'll often use mobile game & \multirow[t]{2}{*}{ self } \\
\hline & $\begin{array}{l}\text { If there is a good mobile game, I would recommend it to } \\
\text { friends }\end{array}$ & \\
\hline \multirow[t]{2}{*}{ Attitude to Use } & If they all play mobile games except me, I will feel pressure & \multirow[t]{2}{*}{ self } \\
\hline & I think the mobile game is a good choice & \\
\hline
\end{tabular}

The questionnaire is in the form of 7- points Likert scale. In order to improve the validity and reliability of the questionnaire, we conducted a small-scale questionnaire for pre-test before large-scale questionnaire and collecting data. Pre-test objects are 50 students of School of Information Management in Hubei University of Economics, asking them to provide advice on understanding the questionnaire items and expression grammar. Finally, according to the interview results and the replies, the items in the original questionnaire were modified to form the final questionnaire.

\subsection{Data Collection}

Most respondents are college students in Wuhan, in addition to ones from government institutions and enterprises. By the way of direct payment, 300 questionnaires were distributed from April 3, 2012 to April 7, 2012, 292 were returned, the response rate was $97.33 \%$. With removal of false, and uncompleted questionnaires, we got a total of 226 valid questionnaires, the effective questionnaire return rate is $75.33 \%$.

\section{Results and Discussion}

\subsection{The Statistical Characteristics of the Sample Population}

This research conducted the sample population characteristics statistics from the returned questionnaires of this empirical survey by using SPSS 16.0, the results are shown in Table 5-1.

Table 5-1. Statistical Characteristics of Population Variables

\begin{tabular}{|lr|r|r|r|}
\hline \multicolumn{2}{|c|}{ Sex } \\
\hline Male & Frequency & Percent & Valid Percent & Cumulative Percent \\
Female & 93 & 41.2 & 41.2 & 41.2 \\
133 & 58.8 & 58.8 & 100.0
\end{tabular}


Sex

\begin{tabular}{|lr|r|r|r|}
\hline & Frequency & \multicolumn{1}{c|}{ Percent } & Valid Percent & \multicolumn{2}{c|}{ Cumulative Percent } \\
\hline Male & 93 & 41.2 & 41.2 & 41.2 \\
Female & 133 & 58.8 & 58.8 & 100.0 \\
Total & 226 & 100.0 & 100.0 & \\
\hline
\end{tabular}

Age

\begin{tabular}{|l|r|r|r|r|}
\hline & Frequency & Percent & Valid Percent & Cumulative Percent \\
\hline 18years and below & 3 & 1.3 & 1.3 & 1.3 \\
$18 \sim 24$ years & 188 & 83.2 & 83.2 & 84.5 \\
$25 \sim 30 y e a r s$ & 24 & 10.6 & 10.6 & 95.1 \\
$31 \sim 40$ years & 7 & 3.1 & 3.1 & 98.2 \\
41years and up & 4 & 1.8 & 1.8 & 100.0 \\
\hline Total & 226 & 100.0 & 100.0 & \\
\hline
\end{tabular}

The highest degree(studying or obtained)

\begin{tabular}{|c|c|c|c|c|} 
& Frequency & Percent & Valid Percent & Cumulative Percent \\
\hline High school & 1 & .4 & .4 & .4 \\
Junior College & 16 & 7.1 & 7.1 & 7.5 \\
University Students & 206 & 91.2 & 91.2 & 98.7 \\
Graduate students & 3 & 1.3 & 1.3 & 100.0 \\
Total & 226 & 100.0 & 100.0 & \\
\hline
\end{tabular}

\begin{tabular}{|c|c|c|c|c|} 
& \multicolumn{5}{|c|}{ Occupation } \\
& Frequency & Percent & Valid Percent & Cumulative Percent \\
\hline The staff of enterprises & 36 & 15.9 & 15.9 & 15.9 \\
Government Civil & 12 & 5.3 & 5.3 & 21.2 \\
Servants & 172 & 76.1 & 76.1 & 97.3 \\
student & 6 & 2.7 & 2.7 & 100.0 \\
others & 226 & 100.0 & 100.0 & \\
\hline Total & & & & \\
\hline
\end{tabular}

Monthly disposable income

\begin{tabular}{|c|c|c|c|c|}
\hline & Frequency & Percent & Valid Percent & Cumulative Percent \\
\hline 800yuan and below & 91 & 40.3 & 40.3 & 40.3 \\
801 1500yuan & 115 & 50.9 & 50.9 & 91.2 \\
1501 3000yuan & 14 & 6.2 & 6.2 & 97.3 \\
3001 5000yuan & 4 & 1.8 & 1.8 & 99.1 \\
5001 8000yuan & 2 & .9 & .9 & 100.0 \\
Total & 226 & 100.0 & 100.0 & \\
\hline
\end{tabular}

It can be seen from Table 5-1, in the 226 valid questionnaires, male respondents accounted for $41.2 \%$, and female respondents accounted for $58.8 \% .83 .2 \%$ of the mobile game user centralized in the 18 24 age group. Students accounted for $76.1 \%$, ranking first among the respondent groups. And the staff of enterprises accounted for $15.9 \%$, which is the second. The third is Government workers, accounting for 5.3\%. In the students group, undergraduate accounted for the vast majority, $91.2 \%$. Monthly disposable income may influence the adoption of mobile games, in this investigation, less than 800 yuan per 
month accounts for 40.3\%, 801 1500 accounted for 50.94\%, 1501-3000 accounted for $6.2 \%, 3001-5000$ accounted for $1.8 \%$, and 5001-8000 accounted for $0.9 \%$.

\section{Table 5-2. Monthly Communication Expenditures of Mobile Phone User}

\begin{tabular}{|l|r|r|r|r|}
\hline & Crequency & Percent & Valid Percent & Cumulative Percent \\
\hline 35yuan and below & 65 & 28.8 & 28.8 & 28.8 \\
36 80yuan & 132 & 58.4 & 58.4 & 87.2 \\
$81 \sim 150$ yuan & 27 & 11.9 & 11.9 & 99.1 \\
$151 \sim 300$ yuan & 1 & .4 & .4 & 99.6 \\
301yuan and up & 1 & .4 & .4 & 100.0 \\
\hline Total & 226 & 100.0 & 100.0 & \\
\hline
\end{tabular}

The monthly expenditure of value-added business

\begin{tabular}{|l|r|r|r|r|}
\hline & Frequency & Percent & Valid Percent & Cumulative Percent \\
\hline 5yuan and below & 82 & 36.3 & 36.3 & 36.3 \\
6 10yuan & 80 & 35.4 & 35.4 & 71.7 \\
11 20yuan & 44 & 19.5 & 19.5 & 91.2 \\
21 40yuan & 18 & 8.0 & 8.0 & 99.1 \\
41yuan and up & 2 & .9 & .9 & 100.0 \\
\hline Total & 226 & 100.0 & 100.0 & \\
\hline
\end{tabular}

Monthly, the most part of communication costs is 36 to 80 Yuan, up to $58.4 \%$, less than 35 Yuan and 81 to 150 Yuan are respectively second and third, account for $28.8 \%$ and $11.9 \%$. While in communication expenditures, there are $71.7 \%$ users in less than 10 Yuan group for their value-added service, $19.5 \%$ in 11 to 20 Yuan group.

Table 5-3. Use of Value-added Services in Mobile Phone

\begin{tabular}{|l|r|r|r|}
\hline & \multicolumn{2}{|c|}{ Responses } & \\
\cline { 2 - 3 } & Number & Percent & Percent of Cases \\
\hline Using mobile games & 93 & $16.0 \%$ & $41.2 \%$ \\
Using Fetion / micro letter / mobile & 199 & $34.2 \%$ & $88.1 \%$ \\
QQ & 73 & $12.5 \%$ & $32.3 \%$ \\
Using mobile phone newspaper & 10 & $1.7 \%$ & $4.4 \%$ \\
Using mobile securities & 31 & $5.3 \%$ & $13.7 \%$ \\
Using wireless music & 117 & $20.1 \%$ & $51.8 \%$ \\
Using micro-blog & 20 & $3.4 \%$ & $8.8 \%$ \\
Using mobile software stores & 39 & $6.7 \%$ & $17.3 \%$ \\
Using other value-added services & & & \\
and products & 582 & $100.0 \%$ & $257.5 \%$ \\
\hline Total & & & \\
\hline
\end{tabular}

In the selection of value-added services, the first and second groups are respectively Fetion / micro letter / mobile QQ and micro-blog, and mobile game accounts for $16 \%$. It shows that most users are willing to use the mobile application services with interactive functions. According to the mobile games can be improved by adding more interactive factors as interactive software requirements. 
Table 5-4. Gender Statistics of the Value-added Services User

\begin{tabular}{|c|c|c|c|c|}
\hline & \multicolumn{2}{|c|}{ sex } & \multirow[b]{2}{*}{ Total } \\
\hline & & male & female & \\
\hline \multirow[t]{4}{*}{ Using of mobile game } & Count & 44 & 49 & 93 \\
\hline & $\%$ within $\$$ The use of the & $47.3 \%$ & $52.7 \%$ & \\
\hline & $\%$ within sex & $47.3 \%$ & $36.8 \%$ & \\
\hline & $\%$ of Total & $19.5 \%$ & $21.7 \%$ & $41.2 \%$ \\
\hline \multirow{4}{*}{$\begin{array}{l}\text { Using Fetion / micro message } \\
\text { / mobile QQ }\end{array}$} & Count & 80 & 119 & 199 \\
\hline & $\%$ within $\$$ & $40.2 \%$ & $59.8 \%$ & \\
\hline & $\%$ within sex & $86.0 \%$ & $89.5 \%$ & \\
\hline & $\%$ of Total & $35.4 \%$ & $52.7 \%$ & $88.1 \%$ \\
\hline \multirow{4}{*}{$\begin{array}{l}\text { Using of mobile phone } \\
\text { newspaper }\end{array}$} & Count & 26 & 47 & 73 \\
\hline & $\begin{array}{l}\% \text { within } \$ \text { The use of the } \\
\text { value-added service products }\end{array}$ & $35.6 \%$ & $64.4 \%$ & \\
\hline & $\%$ within sex & $28.0 \%$ & $35.3 \%$ & \\
\hline & $\%$ of Total & $11.5 \%$ & $20.8 \%$ & $32.3 \%$ \\
\hline \multirow{4}{*}{$\begin{array}{l}\text { Using of mobile phone } \\
\text { securities }\end{array}$} & Count & 6 & 4 & 10 \\
\hline & $\begin{array}{l}\% \text { within } \$ \text { The use of the } \\
\text { value-added service products }\end{array}$ & $60.0 \%$ & $40.0 \%$ & \\
\hline & $\%$ within sex & $6.5 \%$ & $3.0 \%$ & \\
\hline & $\%$ of Total & $2.7 \%$ & $1.8 \%$ & $4.4 \%$ \\
\hline \multirow[t]{4}{*}{ Using of wireless music } & Count & 12 & 19 & 31 \\
\hline & $\begin{array}{l}\% \text { within } \$ \text { The use of the } \\
\text { value-added service products }\end{array}$ & $38.7 \%$ & $61.3 \%$ & \\
\hline & $\%$ within sex & $12.9 \%$ & $14.3 \%$ & \\
\hline & $\%$ of Total & $5.3 \%$ & $8.4 \%$ & $13.7 \%$ \\
\hline \multirow[t]{4}{*}{ Using of micro-blog } & Count & 41 & 76 & 117 \\
\hline & $\begin{array}{l}\% \text { within } \$ \text { The use of the } \\
\text { value-added service products }\end{array}$ & $35.0 \%$ & $65.0 \%$ & \\
\hline & $\%$ within sex & $44.1 \%$ & $57.1 \%$ & \\
\hline & $\%$ of Total & $18.1 \%$ & $33.6 \%$ & $51.8 \%$ \\
\hline \multirow[t]{4}{*}{ Using mobile software stores } & Count & 10 & 10 & 20 \\
\hline & $\begin{array}{l}\% \text { within } \$ \text { The use of the } \\
\text { value-added service products }\end{array}$ & $50.0 \%$ & $50.0 \%$ & \\
\hline & $\%$ within sex & $10.8 \%$ & $7.5 \%$ & \\
\hline & $\%$ of Total & $4.4 \%$ & $4.4 \%$ & $8.8 \%$ \\
\hline \multirow{4}{*}{$\begin{array}{l}\text { Using other value-added } \\
\text { service and products }\end{array}$} & Count & 12 & 27 & 39 \\
\hline & $\begin{array}{l}\% \text { within } \$ \text { The use of the } \\
\text { value-added service products }\end{array}$ & $30.8 \%$ & $69.2 \%$ & \\
\hline & $\%$ within sex & $12.9 \%$ & $20.3 \%$ & \\
\hline & $\%$ of Total & $5.3 \%$ & $11.9 \%$ & $17.3 \%$ \\
\hline Total & $\begin{array}{l}\text { Count } \\
\% \text { of Total }\end{array}$ & $\begin{array}{r}93 \\
41.2 \%\end{array}$ & $\begin{array}{r}133 \\
58.8 \%\end{array}$ & $\begin{array}{r}226 \\
100.0 \%\end{array}$ \\
\hline
\end{tabular}




\section{Table 5-5. Monthly Disposable Income and Communications Expenditure Statistics}

\begin{tabular}{|c|c|c|c|c|c|c|c|}
\hline \multirow{2}{*}{\multicolumn{2}{|c|}{ Monthly disposable income }} & \multicolumn{5}{|c|}{ Communication expense per month } & \multirow{3}{*}{$\begin{array}{r}\text { Total } \\
91\end{array}$} \\
\hline & & \multirow{4}{*}{\begin{tabular}{|r|}
$\begin{array}{c}35 y u a n \\
\text { and } \\
\text { bellow }\end{array}$ \\
43 \\
$47.3 \%$
\end{tabular}} & \multirow{2}{*}{$\begin{array}{r}\begin{array}{c}36 \sim 80 \\
\text { yuan }\end{array} \\
45\end{array}$} & \multirow{2}{*}{$\begin{array}{r}\begin{array}{c}81 \sim 150 \\
\text { yuan }\end{array} \\
3\end{array}$} & \multirow{2}{*}{\begin{tabular}{|r|}
$\begin{array}{c}151 \sim 300 \\
\text { yuan }\end{array}$ \\
0
\end{tabular}} & $\begin{array}{l}\text { 301yuan } \\
\text { and up }\end{array}$ & \\
\hline \multirow{4}{*}{$\begin{array}{l}\text { 800yuan and } \\
\text { follow }\end{array}$} & Count & & & & & 0 & \\
\hline & $\%$ within & & & & & & \\
\hline & $\begin{array}{l}\text { Monthly disposable } \\
\text { income }\end{array}$ & & $49.5 \%$ & $3.3 \%$ & $.0 \%$ & $.0 \%$ & $100.0 \%$ \\
\hline & $\%$ of Total & $19.0 \%$ & $19.9 \%$ & $1.3 \%$ & $.0 \%$ & $.0 \%$ & $40.3 \%$ \\
\hline \multirow[t]{3}{*}{ 801 1500yuan } & Count & 21 & 76 & 18 & 0 & 0 & 115 \\
\hline & $\begin{array}{l}\% \text { within } \\
\text { Monthly disposable } \\
\text { income }\end{array}$ & $18.3 \%$ & $66.1 \%$ & $15.7 \%$ & $.0 \%$ & $.0 \%$ & $100.0 \%$ \\
\hline & $\%$ of Total & $9.3 \%$ & $33.6 \%$ & $8.0 \%$ & $.0 \%$ & $.0 \%$ & $50.9 \%$ \\
\hline \multirow{3}{*}{ 1501 3000yuan } & Count & 1 & 7 & 5 & 0 & 1 & 14 \\
\hline & $\begin{array}{l}\% \text { within } \\
\text { Monthly disposable } \\
\text { income }\end{array}$ & $7.1 \%$ & $50.0 \%$ & $35.7 \%$ & $.0 \%$ & $7.1 \%$ & $100.0 \%$ \\
\hline & $\%$ of Total & $.4 \%$ & $3.1 \%$ & $2.2 \%$ & $.0 \%$ & $.4 \%$ & $6.2 \%$ \\
\hline \multirow[t]{3}{*}{ 3001 5000yuan } & Count & 0 & 4 & 0 & 0 & 0 & 4 \\
\hline & $\begin{array}{l}\% \text { within } \\
\text { Monthly disposable } \\
\text { income }\end{array}$ & $.0 \%$ & $100.0 \%$ & $.0 \%$ & $.0 \%$ & $.0 \%$ & $100.0 \%$ \\
\hline & $\%$ of Total & $.0 \%$ & $1.8 \%$ & $.0 \%$ & $.0 \%$ & $.0 \%$ & $1.8 \%$ \\
\hline \multirow[t]{3}{*}{ 5001 8000yuan } & Count & 0 & 0 & 1 & 1 & 0 & 2 \\
\hline & $\begin{array}{l}\% \text { within } \\
\text { Monthly disposable } \\
\text { income }\end{array}$ & $.0 \%$ & $.0 \%$ & $50.0 \%$ & $50.0 \%$ & $.0 \%$ & $100.0 \%$ \\
\hline & $\%$ of Total & $.0 \%$ & $.0 \%$ & $.4 \%$ & $.4 \%$ & $.0 \%$ & $.9 \%$ \\
\hline \multirow[t]{3}{*}{ Total } & Count & 65 & 132 & 27 & 1 & 1 & 226 \\
\hline & $\begin{array}{l}\% \text { within } \\
\text { Monthly disposable } \\
\text { income }\end{array}$ & $28.8 \%$ & $58.4 \%$ & $11.9 \%$ & $.4 \%$ & $.4 \%$ & $100.0 \%$ \\
\hline & $\%$ of Total & $28.8 \%$ & $58.4 \%$ & $11.9 \%$ & $.4 \%$ & $.4 \%$ & $100.0 \%$ \\
\hline
\end{tabular}

\subsection{Reliability Analysis and Validity Analysis}

5.2.1 Reliability Analysis: Reliability refers to the reliability of the scale, includes stability and consistency. In general, Cronbach's $\alpha$ value in 0.6 to 0.8 is better, greater than 0.8 indicates that the internal consistency is excellent.

Table5-6. Cronbach's a Value of Each Factor and of Factors Deleted Measurement

\begin{tabular}{|l|l|l|l|}
\hline Factor & Cronbach's $\alpha$ value & Measurement items & $\begin{array}{l}\text { Delete the Cronbach's } \\
\text { a measuring item value }\end{array}$ \\
\hline $\begin{array}{l}\text { Perceived } \\
\text { usefulness (PU) }\end{array}$ & \multirow{2}{*}{0.752} & PU1 & 0.645 \\
\cline { 3 - 4 } & & PU2 & 0.655 \\
\cline { 2 - 3 } & PU3 & 0.706 \\
\hline
\end{tabular}




\begin{tabular}{|c|c|c|c|}
\hline \multirow{4}{*}{$\begin{array}{l}\text { Perceived ease of } \\
\text { use (PEOU) }\end{array}$} & \multirow[t]{4}{*}{0.797} & PEOU1 & 0.727 \\
\hline & & PEOU2 & 0.686 \\
\hline & & PEOU3 & 0.724 \\
\hline & & PEOU4 & 0.836 \\
\hline \multirow{3}{*}{$\begin{array}{l}\text { Perceived } \\
\text { Entertainment } \\
(\mathrm{PE})\end{array}$} & \multirow[t]{3}{*}{0.735} & PE1 & 0.690 \\
\hline & & PE2 & 0.679 \\
\hline & & PE3 & 0.581 \\
\hline \multirow{4}{*}{$\begin{array}{l}\text { economic } \\
(\mathrm{FC})\end{array}$} & \multirow[t]{4}{*}{0.635} & FC1 & 0.502 \\
\hline & & FC2 & 0.492 \\
\hline & & FC3 & 0.415 \\
\hline & & FC4 & 0.778 \\
\hline \multirow[t]{4}{*}{ Brand trust (BT) } & \multirow[t]{4}{*}{0.624} & BT1 & 0.773 \\
\hline & & BT1 & 0.522 \\
\hline & & BT3 & 0.446 \\
\hline & & BT4 & 0.537 \\
\hline \multirow{3}{*}{$\begin{array}{l}\text { Subjective norm } \\
\text { (SN) }\end{array}$} & \multirow[t]{3}{*}{0.735} & SN1 & 0.611 \\
\hline & & SN2 & 0.571 \\
\hline & & SN3 & 0.758 \\
\hline \multirow[t]{3}{*}{ Similarity (SL) } & \multirow[t]{3}{*}{0.753} & SL1 & 0.692 \\
\hline & & SL2 & 0.649 \\
\hline & & SL3 & 0.671 \\
\hline \multirow{2}{*}{$\begin{array}{l}\text { use of attitude } \\
\text { (ATU) }\end{array}$} & \multirow[t]{2}{*}{0.884} & ATU1 & -- \\
\hline & & ATU2 & -- \\
\hline \multirow{2}{*}{$\begin{array}{l}\text { Behavioral } \\
\text { intention (BI) }\end{array}$} & \multirow[t]{2}{*}{0.817} & BI1 & -- \\
\hline & & $\mathrm{BI} 2$ & -- \\
\hline
\end{tabular}

The Table 5-6 shows that the Cronbach's alpha coefficient of the entire questionnaire is 0.916 , which means that the reliability and stability of the questionnaire is excellent. At the same time each variable's Cronbach's alpha coefficient is more than 0.6, shows that the internal consistency is good.

5.2.2 Validity Analysis: Validity testing is to confirm whether the data collected can get expected conclusions, reflect the research problems, mainly about content validity and construct validity. For content validity, the questionnaire of this study is on the basis of reference to related literatures, and part of the measure scale is repeatedly used by different researchers, such as subjective norms; and trial investigation was conducted before questionnaires released to modify and improve the questionnaire, therefore, content validity is high. At the same time, the study sample is five times larger than the number of items in questionaire $(226>28 * 5=140)$, to meet the conditions of the analysis of the sample size. In addition, this study selected KMO (Kaiser- Meyer-Olkin) measure and Bartlett sphericity test's results to confirm whether the data is suitable for factor analysis.

Table 5-7. KMO and Bartlett's Test

\begin{tabular}{|l|l|r|}
\hline Kaiser-Meyer-Olkin Measure of Sampling Adequacy & .885 \\
\hline Bartlett's Test of Sphericity & Approx. Chi-Square & $3.184 \mathrm{E} 3$ \\
\cline { 2 - 3 } & Df & 378 \\
\cline { 2 - 3 } & Sig. & .000 \\
\hline
\end{tabular}

Table 5-8. Validity Analysis of Variables $(\mathrm{N}=226)$

\begin{tabular}{|c|c|c|}
\hline Variable & KMO value & Bartlett Spherical test statistic \\
\hline
\end{tabular}




\begin{tabular}{|c|c|c|}
\hline Perceived usefulness(PU) & 0.689 & 0.000 \\
\hline $\begin{array}{c}\text { Perceived ease of } \\
\text { use(PEOU) }\end{array}$ & 0.731 & 0.000 \\
\hline $\begin{array}{c}\text { Perceived } \\
\text { Entertainment(PE) }\end{array}$ & 0.671 & 0.000 \\
\hline The economic cost(FC) & 0.655 & 0.000 \\
\hline Brand trust(BT) & 0.699 & 0.000 \\
\hline Subjective norm(SN) & 0.654 & 0.000 \\
\hline Similarity(SL) & 0.500 & 0.000 \\
\hline The use of attitude(ATU) & 0.500 & 0.000 \\
\hline Behavioral intention(BI) & 0.500 & 0.000 \\
\hline
\end{tabular}

The Table 5-8 shows that the KMO value of entire questionnaire is 0.885 , which is larger than 0.7 and is suitable for factor analysis. KMO value of each variable is larger than 0.5, and the corresponding Bartlett inspection significance probability is 0.000 , that is smaller than the significant level, 0.05, which indicates a high degree of sample adequacy and the suitability of factor analysis. Therefore, the contracture validity of the questionnaire and the factor components is appropriate.

\subsection{Structural Equation Analysis}

\subsubsection{Preliminary Estimates of Model}

(1)Preliminary construction of model

This study combines the ATM model and the integrated features of accepted model of games, trying to understand the factors influencing users in selecting the mobile game service. When studied the mobile game behavior of the users, we applied AMOS7.0 using structural equation for processing to model, compute the standardized regression coefficients calculated for each path (path coefficient) and its statistical significance to understand the causal relationship among every variable, and constructed path diagram among each variable. This study does not consider the effect of control variables, the main is analysis of users' intention. Results are shown as follows in Figure 5-2.

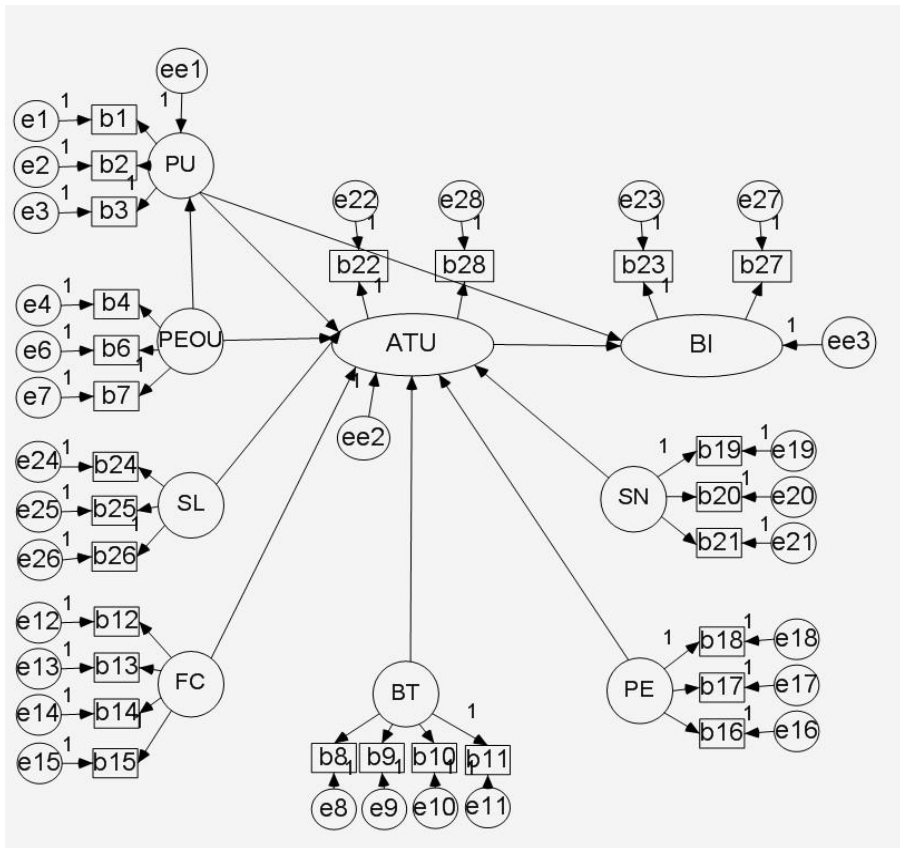

Figure 5-2. The Initial Theoretical Model M1 in AMOS 
The model M1 contains 9 latent variables, 28 observed variables and 31 residual variables. In order to eliminate the impact of the errors in questionnaire data, ensure that the model is able to verify the conclusion, we need mixed variable to match the unrealistic model data .

(2)The goodness of fit of the model

After the establishment of structural equation model, this study adopts AMOS 7.0 to test the goodness of fit between the model and the data. After analyzing the characteristics of fitting index, this study selected the following six fit index to test the model: CMIN/DF, GFI, RMSEA, IFI, PCFI, CFI and ILI.

Table 5-9. Comparison of Fitting Results and Ideal Results between Model and Data

\begin{tabular}{|l|c|c|c|c|c|c|c|}
\hline The revised index & CMIN/DF & GFI & RMSEA & IFI & PCFI & CFI & ILI \\
\hline The fitting results & 1.437 & 0.893 & 0.044 & 0.948 & 0.757 & 0.946 & 0.932 \\
\hline Ideal results & $<3$ & $>0.9$ & $<0.08$ & $>0.9$ & $>0.5$ & $>0.9$ & $>0.9$ \\
\hline
\end{tabular}

It can be seen from the above figure that part of goodness of fit of the model failed to achieve the ideal level, so the theoretical model should be modified.

5.3.2 Amendment Model: In AMOS, correction model can use the modified index (Modification Indices, MI). In AMOS 7.0, we can use the table 5-10 to determine the correction method.

Table 5-10. The Part of Modified Index of Initial Theoretical Model (M1)

\begin{tabular}{|lll|rr|}
\hline & & & M.I. & Par Change \\
\hline Similarity & $<->$ & Subjective norm & 69.148 & .845 \\
Brand trust & $<-->$ & Subjective norm & 31.279 & .473 \\
Brand trust & $<->$ & Similarity & 59.596 & .671 \\
Perceived Entertainment & $<->$ & Subjective norm & 85.911 & .934 \\
Perceived Entertainment & $<-->$ & Brand trust & 58.683 & .660 \\
Perceived ease of use & $<->$ & Similarity & 100.649 & .621 \\
Perceived ease of use & $<-->$ & Brand trust & 69.912 & .431 \\
Perceived ease of use & $<->$ & The economic cost & 39.603 & .063 \\
& & & M.I. & Par Change \\
\hline
\end{tabular}

It can be seen from the above table 5-10 that the correction index of perceived usability and similarity has reached 100.649, and both factors impact on the ease of use attitude, therefore the relationship between the two factors should be amended to add a path between them. Similarly, we need continue to refine and make a comparison of the changes of fit index.

\section{Table 5-11. Comparison between Fitting Results and Ideal Results of} Revised Model and Data

\begin{tabular}{|l|c|c|c|c|c|c|c|}
\hline The revised index & CMIN/DF & GFI & RMSEA & IFI & PCFI & CFI & ILI \\
\hline The fitting results & 2.356 & 0.820 & 0.078 & 0.908 & 0.714 & 0.817 & 0.912 \\
\hline Ideal results & $<3$ & $>0.9$ & $<0.08$ & $>0.9$ & $>0.5$ & $>0.9$ & $>0.9$ \\
\hline
\end{tabular}




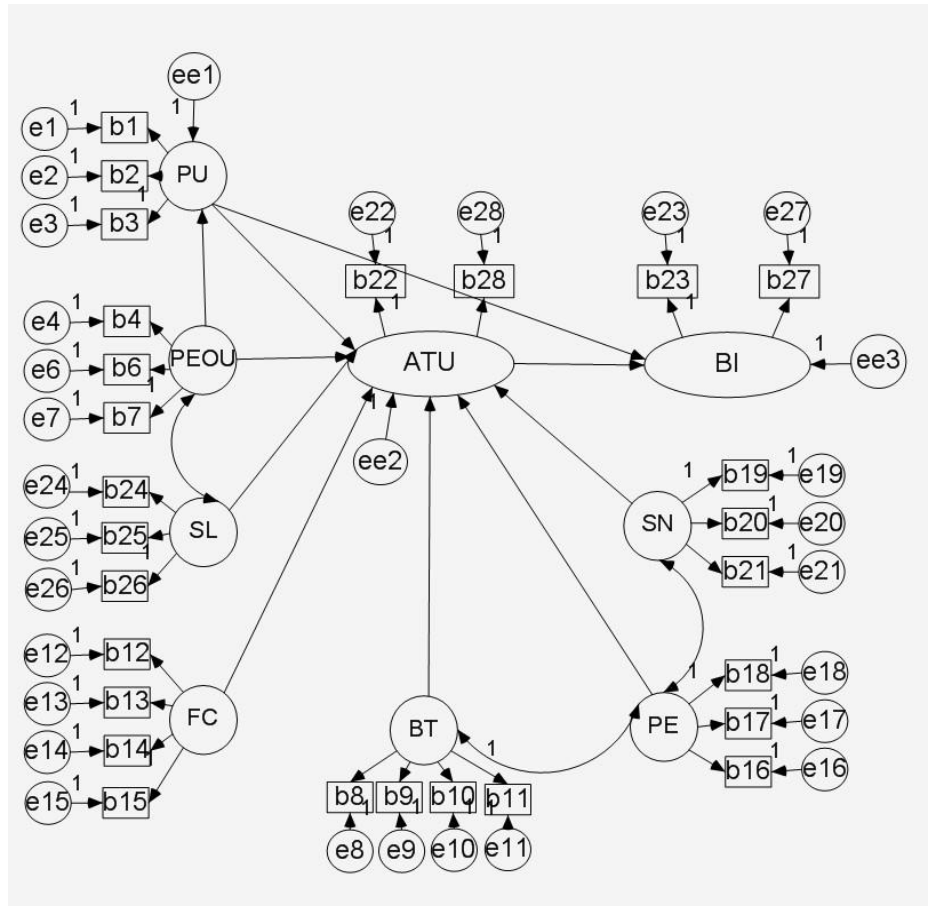

Figure 5-3. The Final Model Diagram

5.3.3 Model Hypothesis Testing: Based on the analysis of the reliability and validity of the questionnaire, as well as a reference to the idea of conceptual model, the study estimates structural equation by using AMOS 7.0 to build a user adoption model. In this study, we use the maximum likelihood parameter estimation method, which can get the path regression coefficient, to validate the 13 hypotheses proposed in this investigation, and the results as shown in Table 5-12.

Table 5-12. The Regression Coefficient Table

\begin{tabular}{|c|c|c|c|c|c|}
\hline \multicolumn{3}{|c|}{ Path } & P value & & Significant level \\
\hline ATU & $<---$ & PU & 0.047 & $*$ & Significant \\
\hline BI & $<---$ & PU & 0.132 & ns & unsignificant \\
\hline PU & $<---$ & PEOU & $<0.001$ & $* * *$ & Significant \\
\hline ATU & $<---$ & PEOU & 0.250 & ns & unsignificant \\
\hline BI & $<---$ & ATU & $<0.001$ & $* * *$ & Significant \\
\hline SN & $<--->$ & PE & 0.006 & $* *$ & Significant \\
\hline ATU & $<---$ & BT & 0.287 & ns & unsignificant \\
\hline ATU & $<---$ & PE & 0.008 & $* *$ & Significant \\
\hline ATU & $<---$ & FC & $<0.001$ & $* * *$ & Significant \\
\hline ATU & $<---$ & SL & 0.742 & ns & unsignificant \\
\hline ATU & $<---$ & SN & $<0.001$ & $* * *$ & Significant \\
\hline PEOU & $<--->$ & SL & $<0.001$ & $* * *$ & Significant \\
\hline BT & $<--->$ & PE & 0.026 & $*$ & Significant \\
\hline SN & $<--->$ & PE & 0.037 & $*$ & Significant \\
\hline
\end{tabular}

From the data in the table, it can be obtained that six paths are significant in the 11 of the structural equation model in this study, and significant resistance test of each path are content to the standard requirements $(|\mathrm{CR}| \geq 1.96, \mathrm{P} \leq 0.05)$. Another 5 paths were not significant. According to the result, the previously proposed hypotheses is shown in Table 5-13. 
Table 5-13. Summary of the Research Hypothesis

\begin{tabular}{|c|c|c|}
\hline Assumption & Assuming content & Verification \\
\hline H1a & $\begin{array}{l}\text { Perceived usefulness has significant positive influence on } \\
\text { the attitude toward using mobile phone game user }\end{array}$ & support \\
\hline H1b & $\begin{array}{l}\text { Perceived usefulness significantly positive influence user } \\
\text { adoption of mobile phone game behavior intention }\end{array}$ & nonsupport \\
\hline $\mathrm{H} 2 \mathrm{a}$ & $\begin{array}{l}\text { Perceived ease of use significantly positive effect on } \\
\text { mobile phone users useful sexy game knowledge }\end{array}$ & support \\
\hline $\mathrm{H} 2 \mathrm{~b}$ & $\begin{array}{l}\text { Perceived ease of use has significant positive influence on } \\
\text { the attitude toward using mobile phone game user }\end{array}$ & nonsupport \\
\hline H3 & $\begin{array}{l}\text { Users of the mobile phone game attitude positively and } \\
\text { significantly affect user acceptance behavior intention }\end{array}$ & support \\
\hline $\mathrm{H} 4$ & $\begin{array}{l}\text { User perception of mobile phone game of the positive } \\
\text { influence the attitude of use. }\end{array}$ & support \\
\hline H5 & $\begin{array}{l}\text { The economic cost of the negative impact of mobile phone } \\
\text { game attitude of use. }\end{array}$ & support \\
\hline H6 & $\begin{array}{l}\text { Users of the mobile game brand trust has significant } \\
\text { positive influence on the attitude toward using mobile } \\
\text { phone game user. }\end{array}$ & nonsupport \\
\hline $\mathrm{H7}$ & $\begin{array}{l}\text { Mobile games and mobile phone performance similarity } \\
\text { positively and significantly affect attitude of user of } \\
\text { mobile game. }\end{array}$ & nonsupport \\
\hline $\mathrm{H} 8$ & $\begin{array}{l}\text { The user subjective norms of mobile phone game cognitive } \\
\text { positively and significantly affect user attitudes }\end{array}$ & support \\
\hline
\end{tabular}

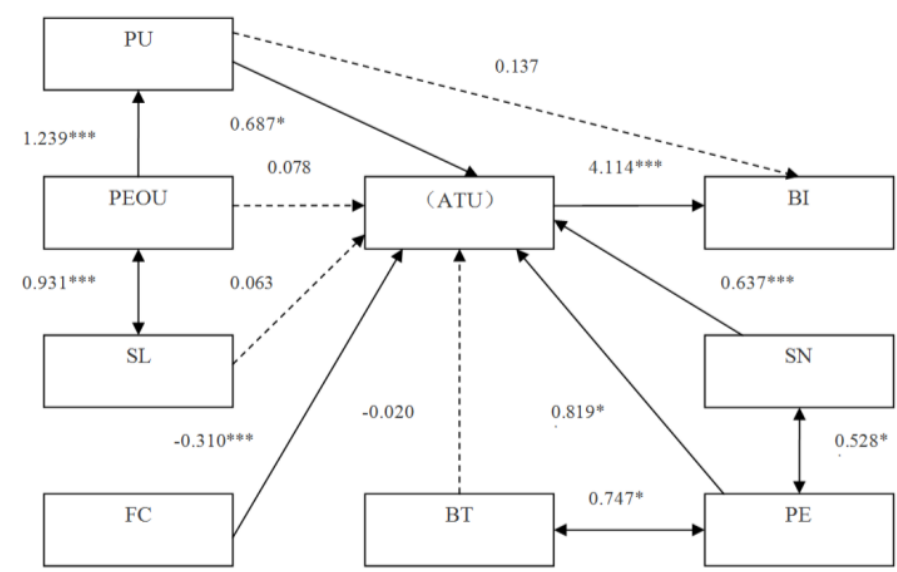

Figure 5-4. Mobile Games Adoption Structural Equation Model

We analyze the above hypothesis test's result from the following four aspects.

(1)Perceived usability and perceived usefulness 
Perceived usability has a significant positive impact on perceived usefulness $(\beta=$ 1.239). If mobile game users feel mobile games is convenient to use and operate, usefulness of the mobile games will be perceived .

(2)Perceived usefulness, perceived usability, perceived entertainment and attitude of use

Perceived usefulness $(\beta=0.687)$ has a significant negative effect on attitude of use. Perceived usefulness means that the mobile game users realize that they are useful and important, so they are willing to adopt mobile games. Perceived Entertainment $(\beta=0.819)$ have a significant and positive effect on attitude of use. It illustrates that visual and tactile pleasure is very important in games for it result in the attitude of use significantly. While perceived usability $(\beta=0.078)$ did not significantly affect the attitude of use. The convenience is less important than entertainment of mobile games' operation to users. The vast majority of survey respondents are 18-24 years old, who can operate mobile games relatively easily, so it is less influent for usability.

(3)Economic cost, brand trust, similarity and attitude of use

The economic cost has a significant negative effect on the attitude of use $(\beta=0.310)$. The economic cost of mobile games includes download traffic and network game traffic charges and the game download fees. When the cost exceeds a certain level, the user would choose other forms of entertainment. Brand trust (beta $=-0.020$ ) and similarity (beta $=0.063$ ) have no significant effect on attitude of use. Due to the high level of similarity in games occurs in present mixed mobile game market, users can easily find alternative games, and it's difficult for them to form a brand loyalty.

(4)The attitude of use, perceived usefulness and behavior intention

The attitude of use positively and significantly affect behavior intention $(\beta=4.114)$. Perceived usefulness has no significant effect on behavioral intention $(\beta=0.137)$. Mobile games give users more of a sense of entertainment, it is a recreational experience.

5.3.5 Management Recommendations: Any mobile game experiences all the stages from development to launch and then fade out. For the sustainable competiveness in mobile game market, we put forward the following recommendations for the development and promotion of mobile games based on the results of this study.

(1)Improving the game quality, enhancing entertainment

Because of the high level of the similarity in today's mobile game market, we should enhance the visual /tactile technology and operation of mobile games. Rather than aspiring low-cost and mass production blindly, we should stand on the point of view of the user to improve user experience.

(2)To carry out the promotion of the game according to the different characteristics of users

Now more and more mobile games users in different ages and occupations, therefore their preferences and needs of the game are also various. According to our research, the largest target customer group is the younger generation, which means we should be young customer-oriented with other groups as a supplement of the marketing method according to their different preferences.

(3)Reducing the cost

Although the heavy investment of R\&D in mobile game, and if the game overpriced, it would be easy to lose user, especially the younger user group. For this issue we can learn from the game like Fruit Ninja Swampy to launch the free version, or launch the limited 
free activities to enhance the users' experience, just like Apple's App store does. In addition, technically optimizing games can reduce the space that the game occupied, the cost of the network traffic and improve the service as well.

(4)Enhancing interaction, with carry out word-of-mouth marketing

With the pace of social life increasing, demand for interactive from social life is also keeping growth. Game developers should develop mobile game to the point under the premise of understanding public demand. In China, the highest value-added service of mobile phone is mobile QQ, micro-blog and other interactive software, that the public desire to communicate with others to realize their social value in the information exchange.

"It is not better in TV than which is recommended by friends or families." Consumers will inevitably have such thoughts about general traditional products, so are mobile games. Establishing mobile games forum can provide a platform for player communication. What's more, users can enhance their awareness and recognition about the game product.

\section{Summary and Future Research}

This study analyzed adoption behavior of mobile games based on technology acceptance model combined with multiple factors. The empirical study shows that perceived usefulness, perceived entertainment, economic cost and subject norm significantly affect the attitude of use, which results in behavior intention to adopt the mobile game. Understanding these mobile game adoption factors will help mobile game developers and operators to enlarge its application.

Although, there are still some shortcomings in this study due to the sample scope and time limitations. And there are other factors affecting the adoption behavior of mobile phone games. Therefore, this study can be improved and expanded in following fields: Future research could extend the study to consumers across the country groups, including consumers of different culture, ages, income levels and industries to enhance the contribution of the study to user acceptance and mobile commerce.

\section{Acknowledgements}

This work was partially supported by a grant from the Special supporting project of China Postdoctoral Science Foundation (No. 2012T50674), and S\&T project of Hubei Provincial Department of Education (No.D20132201).The first version of the work is represented in 2014 International Conference on Logistics, Informatics and Services Sciences (LISS'2014,Berkeley, California, USA).

\section{References}

[1] China Internet Network Information Center, (CNNIC), Chinese Internet Development Statistics Report (33th) (2014).

[2] J. Ruggill and K. S. McAllister, "Moving Targets: The Constant Change of Mobile Game Development", Journal for Computer game Culture, vol. 5, no. 1, (2014), pp.135-149.

[3] P. Hu and K. Zhu, "Strategy Research on the Performance Optimization of 3D Mobile Game Development Based on Unity", Journal of Chemical and Pharmaceutical Research, vol. 6 , no. 3, (2014), pp. 785-791.

[4] P. Harris, R. Rettie and C. C. Kwan, "Adoption and Usage of M-Commerce: A Cross-Cultural Comparison of HongKong and the United Kingdom, Journal of Electronic Commerce Research", vol. 6, no. 3, (2012), pp. pp. 210-224.

[5] L. Zhang, J. Zhu and Q. Liu, "A meta-analysis of mobile commerce adoption and the moderating effect of culture", Computers in Human Behavior, vol. 28, no.5, (2012) September, pp. 1902-1911.

[6] D. Feng, "Design and Implementation of Mobile Phone Games Based on J2ME Platform", University of Electronic Science and Technology, China (2007). 
[7] Z. Zhou, "Design and Implementation of Game of the J2ME Mobile Phone based on Bluetooth Technology", University of Electronic Science and Technology, China (2009).

[8] T. Wang and G. Sheng, "Design and Implementation of 3D Multiplayer Mobile Phone Game Based on Bluetooth", Computer Knowledge and Technology, vol. 7, no. 3, (2009), p. 33.

[9] Z. Deng, Y. Lu, B. Wang, J. Zhang and K. Wei, "An Empirical Analysis of Factors Influencing Users' Adoption and Use of Mobile Services in China", International Journal of Mobile Communications archive, vol. 8, no. 5, (2010) August, pp. 561-585.

[10] J. Lin, B. Wang, N. Wang and Y. Lu, "Understanding the Evolution of Consumer Ttrust in Mobile Commerce: a Longitudinal Study", Information Technology and Management, vol. 15, no. 1, (2014), pp 37-49.

[11] Z. Deng, Y. Lu, J. Zhang and B. Wang, "Subscription of Mobile Services: The Role of TAM and Trust", 4th International Conference on Wireless Communications, Networking and Mobile Computing, (2008) October 12-14, pp. 1-4; Dalian, China.

[12] C. Wang, "The Influence Factors of the User Intention to Use Mobile Phone Game", Beijing University of Posts and Telecommunications (2010).

[13] C. Liu, "Analysis on the Success Factors of Games-based on the Theory of Consumer Acceptance", E-Commerce, vol. 9, (2013), pp. 65-67.

[14] F. Martin and I. Ajzen, "Belief, Attitude, Intention, and Behavior: An Introduction to Theory and Research Reading”, Addison-Wesley, Massachusetts (1975).

[15] I. Ajzen, "The Theory of Planned Behavior, Organizational Behavior and Human Decision Processes, vol. 50, no. 2, (1991), pp. 179-211.

[16] F. D. Davis, "Perceived Usefulness, Perceived Ease of Use, and User Acceptance of Information Technology", MIS Quarterly, vol. 13, no. 3, (1989), pp. 319-340.

[17] K.Younghwa, K. A. Larsen and R. T. Kai, "The Technology Acceptance Model: Past, Present, and Future Communications of the Association for Information Systems", vol. 12, no. 1, (2003), pp. 752-780.

[18] C. Lin, H. Gu and Y. He, "An Empirical Study of User Behavioral Intention to Accept of Mobile TV: An Integration of TAM with Entertainment", In: IEEE Ninth International Conference on E-business Engineering, (2012) August 12-15, pp. 227-231, Hangzhou, China.

[19] L.-Y. Leongl, K.-B. Ooi, A. Y.-L. Chong and B. Lin, "Influence Of Individual Characteristics, Perceived Usefulness and Ease of Use on Mobile Entertainment Adoption", International Journal of Mobile Communications, vol. 9, no. 4, (2011), pp. 359-382.

[20] L. van de Wijngaert, W. Pieterson and M. L. Teerling, "Influencing Citizen Behavior: Experiences from Multichannel Marketing Pilot Projects", International Journal of Information Management, vol. 31, no. 5, (2011) , pp. 415-419.

[21] Y. K. Choi, S. Yoon and H. P. Lacey, "Online Game Characters' Influence on Brand Trust: Self-Disclosure, Group Membership, and Product Type”, Journal of Business Research, vol. 66, no. 8, (2013), pp. 996-1003.

[22] L. Zhao, Y. Lu and B. Wang, "Cultivating the Sense of Belonging and Motivating User Participation in Virtual Communities: A Social Capital Perspective", International Journal of Information Management, vol. 32 , no. 6, (2012) , pp. 574-588.

[23] J. Schepers and M. Wetzels, "A Meta-Analysis of the Technology Acceptance Model: Investigating Subjective Norm and Moderation Effects", Information \& Management, vol. 44, no. 1, (2006), pp. 90-103.

[24] E. P. Pedersen, "Adoption of mobile internet services: an exploratory study of mobile commerce early adopters", Journal of Organizational Computing and Electronic Commerce, vol. 15, (2005), pp. 203-222.

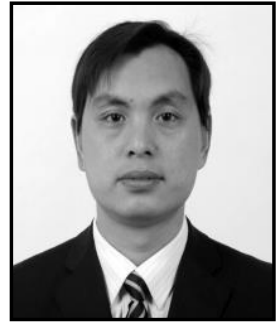

Guoyin Jiang, he is an associate Professor of Hubei University of Economics. He received his PhD in Management Science and Engineering from the Huazhong University of Science and Technology, China. His research interests include decision support systems, management System Simulation, and e-commerce. He has published over 40 professional papers in refereed journals and national and international conference proceedings. 